\title{
TeLling in English, Norwegian and French: A three-way contrast
}

\author{
Thomas Egan \\ Inland Norway University of Applied Sciences (Norway)
}

This paper presents the results of a study of double object constructions containing the cognate verbs English tell and Norwegian fortelle, based on data from the English-Norwegian Parallel Corpus. The results show that there is a certain degree of correspondence between the two verbs in constructions with nominal direct objects, with less mutual correspondence in constructions with finite clausal objects, very little correspondence in constructions with objects in the form of direct speech, and none whatsoever in the case of non-finite clausal objects, which only occur with tell. The paper then expands the topic to include TELL predications in French. The data were retrieved from the Oslo Multilingual Corpus. It transpires that the form of French translations of Norwegian expressions are more similar, at least for some constructions, to the Norwegian originals than are their English counterparts.

Keywords: ditransitives, cognates, TELL verbs, SAY verbs, direct speech, English/French/Norwegian

\section{Introduction}

This paper is divided into two parts. The first part presents the results of a study of double object constructions containing the cognate verbs English tell and Norwegian fortelle, based on data from the English-Norwegian Parallel Corpus (ENPC: see Johansson, 2007: 10). It is part of a larger study of a handful of cognate verbs, coding actions of GIVING, SENDING, BRINGING, LENDING and SELLING, as well as TELLING. The English verb tell is the second most frequent ditransitive verb in English, after give (Mukherjee, 2005: 119), as well as the second most frequent communication verb, after say (Biber et al., 1999: 368; Viberg, 1996: 156). It differs from most other English communication verbs in occurring in the ditransitive construction (Huddleston and Pullum, 2002: 310). The second part of the paper examines translations into both English and French of Norwegian TELL predications in the Oslo Multilingual Corpus (OMC: see Johansson, 2007: 18). The reason for including French in the study is that it resembles Norwegian, but not English, in containing a SAY verb (dire) that partakes of the dative alternation.

An analysis of GIVE constructions in English and Norwegian shows that these are remarkably similar, both in their semantics and their distribution (Egan, forthcoming). The distribution of the ditransitive and prepositional dative constructions in the two languages in the ENPC is actually more similar than it is between the different varieties of spoken English 
analysed by Szmrecsanyi et al. (2017). Moreover, the semantic network of the English and Norwegian verbs is almost identical, in terms of both central and peripheral senses. The only difference of note is a greater tendency for give to occur in light verb constructions (give a kiss/glance/push etc.).

The TELL verbs in the two languages differ from the GIVE verbs in at least one important respect. As pointed out by Mukherjee (2005: 127), the direct object is much more likely to take the form of a clause, as in (1) and (2).

(1) He did once tell me that he hated shaking hands. (RDA1) ${ }^{1}$

Han fortalte meg en gang at han hatet å håndhilse. (RDA1T)

(2) One time he told me what the name of the town meant. (NG1)

En gang fortalte han meg hva navnet på byen betydde. (NG1T)

The constructions in the translations of the that-clause in (1) and the wh-clause in (2) mirror those of the originals. ${ }^{2}$ In this paper the following three research questions are addressed.

1. How similar to/different from one another are the distributions of double object constructions containing the verbs tell and fortelle in the original texts in English and Norwegian?

2. Are there some kinds of tokens that are either usually or never translated by congruent constructions? If never, what characterises the divergent translations?

3. What are the French translation correspondences of the English and Norwegian constructions?

The first of these research questions is answered by comparing the source texts in English and Norwegian, the second by comparing the target texts in Norwegian and English with their sources, and the third by comparing French and English translations to one another and to their Norwegian sources. As for the structure of this paper, section 2 presents the corpus data and the methods employed to analyse them. Section 3 compares English and Norwegian with respect to constructions containing various types of direct objects. Section 4 expands the topic to include TELL predications in French, and finally, section 5 contains a summary and conclusion.

\section{Theory, corpus and method}

The reason for studying cognate verbs that occur in identical syntactic constructions is grounded in the assumption that translators, in addition to attempting to render the semantic and pragmatic import of their source texts, will tend to employ congruent constructions where these are available in the target language (see Ebeling, 1998: 169). Moreover, cognates tend to trigger cognates in the mental lexicon of bilingual speakers (Paradis, 2004: 218, Vandevoorde, 2020: 205-209). When a cognate lexeme can be used in an equivalent grammatical construction in a target language, one might expect translators to choose to employ them both.

\footnotetext{
${ }^{1}$ The first part of the code 'RDA1' refers to the text in the English-Norwegian Parallel Corpus from which the example has been taken, with 'RDA' being the initials of the Egan. 'RDA1T' stands for the translation of the same text. The full titles of the original works and the translations are listed in Johansson (2007: 329-338).

2 The labels 'that-clause' and ' $w$ h-clause' will be used throughout for subordinate declarative and interrogative clauses, respectively, in all three languages.
} 
Numerous papers have been published on double object constructions in English. Mukherjee (2005: 3-63) contains a comprehensive overview of ditransitive constructions, and recent years have seen the publication of multifactorial studies of the English dative alternation by Bresnan and Hay (2008), Bresnan and Ford (2010), Szmrecsanyi et al. (2017), Röthlisberger et al. (2017), among others. Much less has been written about these constructions in Norwegian: among those who have addressed them are Åfarli (1992), Brøseth (1998), Tungseth (2008) and Lohndal (2011). Andersen et al. (2012: 24) state that "the DA [dative alternation] in Norwegian is very similar to that in English, at least in the most straightforward cases". As mentioned above, Egan (forthcoming) shows considerable similarity in the case of the prototypical GIVE verbs in the two languages.

Since one of the aims of the present study is to compare the two types of double object constructions, the ditransitive and the prepositional dative, the data investigated are limited to active voice examples with an explicitly coded TELLER (except in the case of imperatives) and explicitly coded THEMEs, encoded syntactically as direct objects, and RECIPIENTs, encoded syntactically as indirect or prepositional objects. Thus, examples of monotransitive TELL constructions in the source texts are excluded from consideration. Also excluded are constructions of the type labelled 'indirect object + prepositional object' by Quirk et al. (1985: 1208), as in 'tell $x$ about $y$ ', 'tell about' being considered a prepositional verb, as in Mukherjee (2005: 126). Examples with passive verbs, in which either the THEME or the RECIPIENT is encoded as a syntactic subject rather than an object, are also not included, since these normally contain just two participants.

Two corpora are used in the present study. The initial comparison of English and Norwegian is based on data from the ENPC, which contains extracts from 50 English texts, both fictional and non-fictional, aligned with their translations into Norwegian, and extracts from 50 texts in Norwegian with their English translations. These extracts are between 10,000 and 15,000 words in length, yielding a total of about 650,000 words of both original text in, and translations into, each language. Although the corpus is rather small, the facts that it is bidirectional and that the two lexemes in the study are both relatively common renders it suitable for the present study. All tokens containing forms of the lemmas tell and fortelle in the original texts were extracted from the corpus. For English, the forms are tell, tells, telling and told. For Norwegian, the forms are fortell (imperative), fortelle (infinitive), forteller (present), fortalte (preterite) and fortalt (past participle). The tokens retrieved were sorted manually to only include all instances with an explicit subject (except in the case of imperatives) and two explicit objects. The direct object in English may be a finite clause, as in (1) and (2), a nonfinite clause, as in (3), or an NP, as in (4). It may also consist of direct speech, which in both written English and Norwegian is enclosed in quotation marks, as in (5)-(7). When the direct object takes the form of a clause or direct speech, the RECIPIENT is always encoded by an indirect object, never a prepositional one (Levin, 1993: 203).

(3) Then she told Mum to leave. $(\mathrm{BO} 1)^{3}$

Så ba hun mamma gå. (BO1T)

Then asked she Mum (to) leave. ${ }^{4}$

\footnotetext{
${ }^{3}$ Note that Huddleston and Pullum (2002: 1207) would analyse the non-finite clause in (3) as a catenative complement rather than a direct object. There is also a construction in which a to-infinitive clause is preceded by a wh-word, as in ' $x$ told y wh. to-infinitive'. Huddleston and Pullum (2002: 1264) point out that this sort of clause resembles a finite $w h$-clause in its distribution. I have classified examples of this construction as $w h$-clauses.

${ }^{4}$ An English gloss is provided in italics for the relevant part of the predication in Norwegian whenever this is not faithfully rendered by the English translation in the corpus, or when it is not a faithful rendition of an English original.
} 
(4) I'll tell you a story. (OS1)

Jeg skal fortelle deg en historie. (OS1T)

(5) He told her, deadpan, "Love can happen to the elderly, too." (AH1)

Han sa gravalvorlig: "Kjorligheten kan komme til gamlinger også." (AH1T)

He said, serious as the grave, "Love can come to oldies too".

(6) "The King of England uses only five inches of bath water," Aunt would tell them. (AB1)

"Kongen av England bruker bare fem tommer med badevann," fortalte tante dem. (AB1T)

... told Auntie them.

(7) "Even then," Celia told Andrew, "Sam took some persuading." (AH1)

"Selv da trengte Sam en god del overtalelse," sa Celia. (AH1T)

... said Celia.

It should be noted that Mukherjee (2005) excludes examples such as (6) and (7) from his classification of ditransitive constructions, limiting cases with direct speech THEMEs to instances like (5) where these follow, rather than precede, or interrupt, the reporting predication (see also Huddleston and Pullum, 2002: 1026). For this contrastive study, I decided to include all three types since one type may be translated by another, as in (7) (see also Bourne, 2002: 245).

Section 4 expands the topic to include TELL predications in French, which resembles both English and Norwegian in containing a TELL verb, raconter, and Norwegian, but not English, in containing a SAY verb, dire, which occurs in the ditransitive. The data are from the Norwegian-English-German-French part of the Oslo Multilingual Corpus (OMC). This part of the OMC contains a total of 408,558 words from five Norwegian novels, together with their translations into English, French and German (see Johansson, 2007 for details). Two methods are employed to retrieve relevant examples from the OMC. The first method takes as its starting point Norwegian ditransitive fortelle constructions, which function as tertia comparationis for their English and French translations. The second method starts with all instances of ditransitive tell in the English target texts, which are compared to their corresponding French translations and Norwegian sources.

\section{English and Norwegian TELL constructions in the ENPC}

The original English texts in the ENPC contain 772 examples of tell, 449 of which (58\%) occur in double object constructions. For Norwegian, the total number for fortelle is 536, and 120 examples $(22 \%)$ of these occur in double object constructions. These types of constructions would therefore seem to be more salient for the English verb. 15\% of the English examples and $15 \%$ of the Norwegian ones are from non-fiction texts. I chose not to distinguish between fiction and non-fiction texts in this study since the distinction is a crude one and the majority of the relevant examples from non-fiction are found in narrative texts, such as Peter Mayle's $A$ Year in Provence. ${ }^{5}$ Section 3.1 contains an overview of the various types of THEME and RECIPIENT that occur with these constructions in the source texts in the two languages. Section 3.2 examines the distribution of the two forms of double object construction in the source texts.

\footnotetext{
${ }^{5}$ One difference between the two sets of texts is the greater tendency for the TELLER in non-fiction to be inanimate, the RECIPIENT generic and the verb in the present tense, yielding a construction that may be paraphrased 'the evidence shows (us) that'.
} 
Section 3.3 presents the translation correspondences of the constructions in the two sets of target texts.

\subsection{Types of THEME and RECIPIENT}

The RECIPIENT in TELL constructions is almost invariably animate. It is encoded in most cases by either a personal pronoun or a proper noun (93\% in English and 87\% in Norwegian). The remainder, with a single exception, cited as (8), are either encoded by NPs with an animate head, such as "the boys" and "den gamle kvinnen" (the old woman), or a head metonymically related to an animate, such as "the staff meeting" and "politiet" (the police). (8) is the only example where there is no doubt that the RECIPIENT is incapable of receiving the communication. In this case the TELLER is merely giving voice to her disappointment and frustration.

(8) Jeg forteller sykkelen at jeg er gravid, tross Lippes loop. (CL1)

I tell the bicycle that I'm pregnant, in spite of the Lippes coil. (CL1T)

As for THEMEs, we have already seen examples in (1)-(7) of the five types of direct object we find with English tell: NPs, that-clauses, wh-clauses, to-infinitive clauses, and direct speech. In the original Norwegian texts in the ENPC, there are only three types of THEME, NPs as in (9), that-clauses, as in (10), and wh-clauses, as in (11).

(9) Og så fortalte hun dem sin historie. (TTH1)

Then she told them her story. (TTH1T)

(10) Jeg forteller Nick at jeg skal gifte meg i New York. (KT1)

I tell Nick that I am going to get married in New York. (KT1T)

(11) Han fortalte meg hvordan det foregikk. (EG2)

He told me how it happened.

He told me all about how it's done. (EG2T)

Fortelle does not occur with a clausal infinitive object to code an instruction. Nor is it used in the original Norwegian texts in a construction with an explicit RECIPIENT to report direct speech. That the ditransitive construction is not impossible in Norwegian is shown by the idiomatic translation in (6). Figure 1 shows the distribution of tell and fortelle in the various constructions.

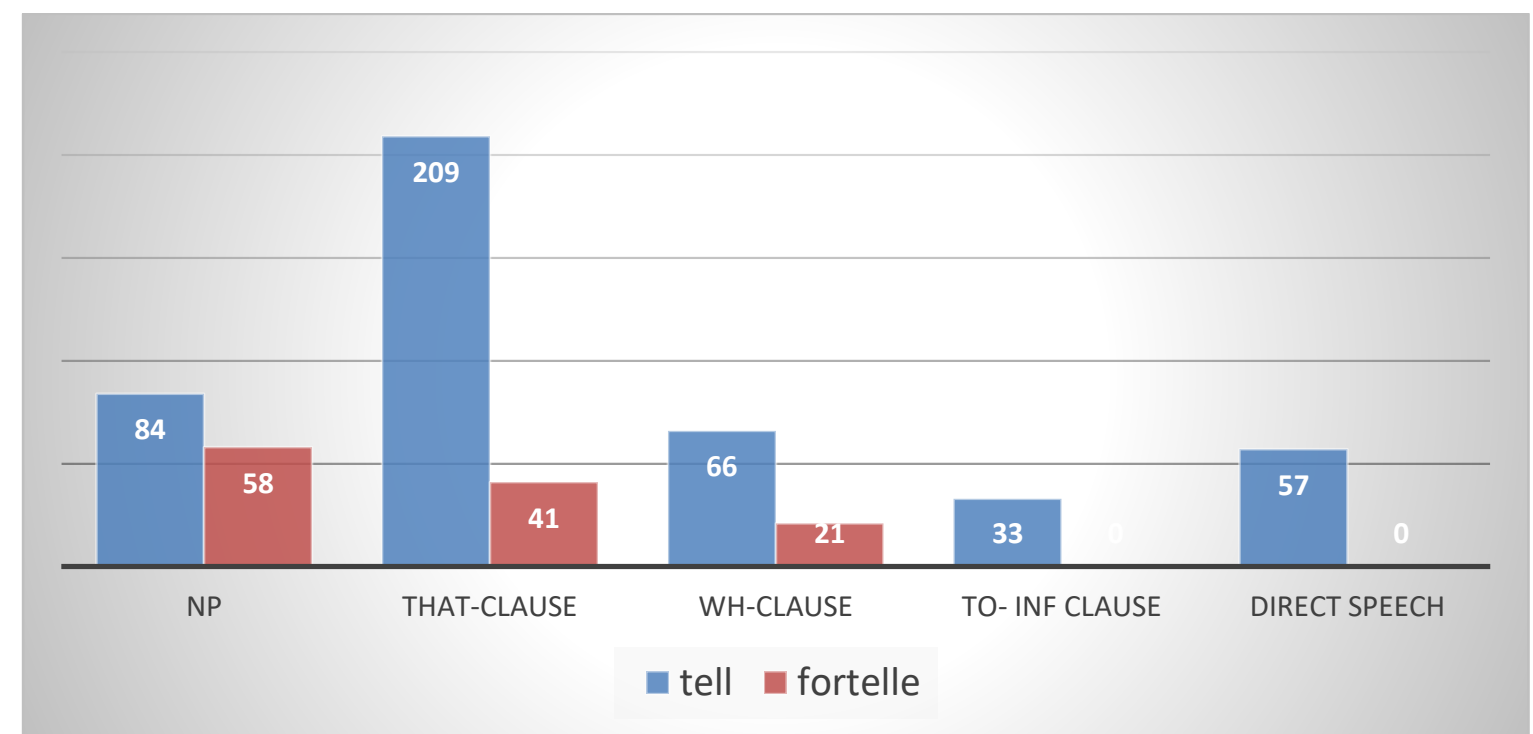

Figure 1. Raw numbers for tell $(\mathrm{n}=449)$ and fortelle $(\mathrm{n}=120)$ in double object constructions in original texts. 
The figure shows that not only is tell almost four times as common as fortelle in double object constructions, but that the two verbs differ with respect to their relative distribution with the three types of THEME with which both occur. The that-clause is the most salient form of direct object of tell, occurring in $47 \%$ of tell double object constructions, and $27 \%$ of all occurrences of tell (the corresponding proportion in Mukherjee, 2005, based on ICE-GB, is 30\%). For Norwegian, the NP form of direct object accounts for $49 \%$ of examples of fortelle with two objects, but just $11 \%$ of all tokens of fortelle. The fortelle construction with an NP THEME and an explicitly coded RECIPIENT can therefore not be said to represent a particularly salient construction with the verb fortelle.

\subsection{Ditransitive versus prepositional dative}

All examples cited thus far have been of ditransitive constructions. However, both tell and fortelle can occur with the prepositional dative, as in (12) and (13).

(12) There is no one I would ever tell this to, except Cordelia. (MA1)

Det er ingen jeg ville finne på å si dette til, bortsett fra Cordelia. (MA1T) ....say this to...

(13) Men de fortalte siden alle detaljer til alle som ville høre. (HW2)

...to everyone who wanted to hear.

But they later told the details to anyone who wanted to know. (HW2T)

Table 1 shows how often the two verbs occur in the constructions with NP THEMEs (there are no examples in either language of the prepositional dative with a TELL verb and a clausal THEME).

Table 1. Ditransitive vs. Prepositional dative with TELL verbs and NP THEMEs in ENPC.

\begin{tabular}{|l|l|l|l|l|}
\hline & \multicolumn{2}{|c|}{ Ditransitive } & \multicolumn{2}{|c|}{ Prepositional dative } \\
\hline tell & 83 & $98.8 \%$ & 1 & $1.2 \%$ \\
\hline fortelle & 46 & $79.3 \%$ & 12 & $20.7 \%$ \\
\hline
\end{tabular}

Table 1 shows that fortelle is much more likely than tell to occur in the prepositional dative construction. According to Mukherjee (2005: 123), the prepositional dative is "hardly ever used" in adult speech in English. Indeed, example (12) is the only such example with tell among 84 tokens in the ENPC with NP THEMES. In it the RECIPIENT is the antecedent of a relative clause containing the preposition. In this case the ditransitive ("There is no one I would ever tell this, except Cordelia') would not be felicitous. In eight of the twelve examples of the prepositional dative in Norwegian the THEME is encoded by a pronoun, either den/det (it) or dette (this). Only two of the RECIPIENTs in these examples are pronominal, and both of these are indefinite noen (anyone). Four of the 12 examples receive congruent translations, including three of the four containing full nominal direct objects, as in (14).

(14) Men de fortalte siden alle detaljer til alle som ville høre. (HW2)

But they told later all the details to everyone who wanted to hear.

But they later told the details to anyone who wanted to know. (HW2T)

While the translation in (14) is perfectly idiomatic, as are the other three prepositional dative translations, the fact that there is only one example of this construction in the original English 
texts in the ENPC would suggest that its rarity in spoken English noted by Mukherjee (2005: 123 ) is also true of the written mode.

\subsection{Translation correspondences of tell and fortelle}

The translators of the texts in the ENPC adopt four main strategies in translating double object TELL predications; sometimes they use a syntactically congruent translation containing either the corresponding TELL verb or another verb, and sometimes a syntactically divergent translation containing the corresponding TELL verb or another verb. There are 29 zero translations into Norwegian and two into English. The various strategies will be illustrated in turn, starting in (15)-(16) with congruent translations employing the TELL verb.

(15) Have I told you my Theory of Life, by the way? (JB1) Har jeg fortalt deg min Livsteori, forresten? (JB1T)

(16) Jeg fortalte deg at vi fant en av dem helt ute i trappehuset. (GS1) I told you we found one of them right on the stairway. (GS1T)

Congruent translations with the TELL verb are used by translators in both directions and with all three types of direct object that occur in both sets of original texts. This form of translation is maximally congruent, with the cognate verb being used in the identical syntactic construction.

In some translations, exemplified here by (17)-(18), the syntax of the original is preserved, but another verb is used instead of tell/fortelle. (An overview of alternative verbs is given for English in Table 3 and for Norwegian in Table 4.)

(17) Han fortalte det til Henry som lo støyende. (OEL1) He said it to Henry who laughed noisily. (OEL1T)

(18) We wouldn't start telling people he was dead until after I'd talked to his lawyers. (DF1)

Vi skulle ikke begynne å meddele folk at han var død før jeg hadde snakket med advokatene hans. (DF1T)

...inform...

We saw in section 3.2 that English writers tend to avoid the prepositional dative with tell. However, the ditransitive is not an option in (17) because of the relative clause modifying the RECIPIENT.

Sometimes translators prioritise the cognate lexeme at the expense of the construction, by retaining the TELL verb in a syntactically divergent translation, as in (19), in which the THEME is omitted, and (20) which retains the THEME but omits the RECIPIENT.

(19) Det er ikke verdt vi forteller henne dette. (THA1)

...tell her this....

We'd better not tell her. (THA1T)

(20) I take it your mother told you I stopped by. (SG1)

Jeg går ut fra at Deres mor har fortalt at eg var innom. (SG1T)

...told that I....

There are no Norwegian translations like (19) that omit the THEME, which is implicit in the cotext. There are, on the other hand, four examples that resemble (20). In these, the translators omit the RECIPIENT, but also insert om (about) before the THEME, as shown in (21). There are also seven translations into English and two into Norwegian that retain the TELL verb and the RECIPIENT but encode the THEME in an om/about (or of) phrase, as in (22)-(23). 
(21) "You promised to let Simon tell us his problem." (RDA1)

"Du lovte å la Simon fortelle om sine problemer." (RDA1T)

...tell about his problems.

(22) Hun fortalte det til Sol. (HW1)

...told it to Sol

She told Sol about it. (HW1T)

(23) He'd told me nothing about any love life. (DF1)

Han hadde ikke fortalt meg om noe kjærlighetsliv. (DF1T)

... had not told me about ...

There are five divergent translations into Norwegian that resemble (23) in recoding the THEME in an om phrase, but that contain a verb other than fortelle, such as be (ask) in (24). 59 translations into Norwegian and two into English exhibit the dative alternation (see Table 2), almost always in the direction of the prepositional dative, and normally with a SAY verb, as in (25) and (26). We saw in Table 1 that the prepositional dative is much more common in the original Norwegian texts. This difference in distribution is also reflected in the translated texts, presumably as a result of what Halverson (2017: 14) calls "magnetism", exerted by the structure of the target language.

(24) Mister O'Connell never told us to get out or stay quiet. (RDO1)

Herr O'Connell $b a$ oss aldri om å komme oss ut eller være stille. (RDO1T)

.... asked us never about to get us out...

(25) Slikt kunne jeg ikke fortelle mor. (MN1)

...tell mother...

But I couldn't say such things to Mother. (MN1T)

(26) I won't pay till you tell that boy to apologise to me. (BO1)

Jeg betaler ikke før du sier til den gutten at han skal be om unnskyldning. (BO1T) ... say to that boy that he...

There are as many as 131 examples, over a third of the total number of translations into Norwegian, that omit the RECIPIENT and employ an alternative verb, which again is often $s i$, as in (27). (28) is one of just eight translations into English which employ this strategy.

(27) Our mother tells us which pages to do. (MA1)

Moren vår sier hvilke sider vi skal gjøre. (MA1T)

...says which pages...

(28) Søster Vera fortalte meg bare at tante var død. (EG1)

Sister Vera told me only that auntie was dead.

Nurse Vera just said my aunt was dead. (EG1T)

One final translation strategy that should be exemplified is the greater number of zero translations into Norwegian, 29 (6.5\%) as compared to just two (1.9\%) into English. Both of the English translations, one of which is cited as (29), contain ingen (no one) as the TELLER.

(29) For ingen skulle fortelle ham at møblene var fra Ikea eller at nipsgjenstandene kom fra en eller annen basar på Grønland! (EG2)

Because no one was going to tell him that the furniture was from IKEA or the decorations from some second-hand shop or other in Gronland [a district in Oslo]. Because it was clear that neither furnishings nor ornaments came from chain stores. (EG2T) 
(30) Andrew told his patient, "I'm happy for you, Mary." (AH1) Andrew snudde seg mot pasienten. "Jeg er så glad, Mary Rowe." (AH1T) Andrew turned towards the patient. "I am so happy, Mary Rowe".

(31) Will you listen while I tell you what is really bothering me? (RDA1) Vil dere vite hva som virkelig plager meg? (RDA1T) Do you want to know what's really bothering me?

Example (29) does not describe a genuine act of communication. The expression glossed as 'no one was going to tell him' is idiomatic and indicates a degree of conviction on the part of the RECIPIENT of the falsehood of the predication in the that-clause. Both (30) and (31) encode real communicative acts, but in both cases the TELLER and RECIPIENT can be inferred from the context. In other words, these are textbook examples of implicitation (Vinay and Darbelnet, 1995: 344). Pípalová (2012: 83) notes a similar tendency for what she calls the 'reporting frame', by which she means the clause containing a reporting verb such as tell, to be omitted with Direct Speech THEMEs in translations from English into Czech and vice versa.

Figures 2 and 3 contain details of the main types of translation strategies employed by the two sets of translators, into English and Norwegian respectively.

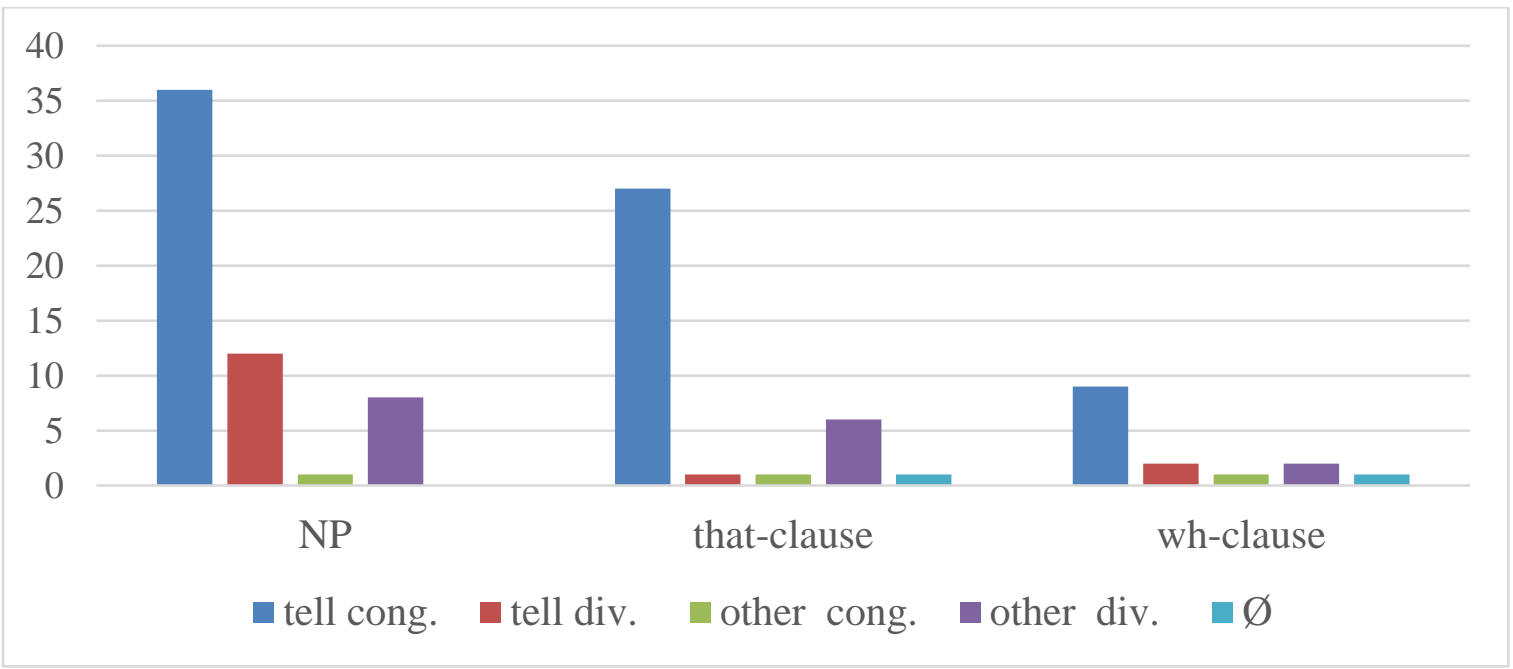

Figure 2. Strategies employed by translators from Norwegian into English in raw numbers.

Figure 2 shows that, for all three double object fortelle constructions, the English translators tend to opt for tell, most often in a congruent translation. In other words, they faithfully stick both with the construction and with the cognate lexeme. To (over-)generalise, in constructions where the translators can use fortelle in Norwegian, they are likely to retain the form of the construction with the verb tell in English. When it comes to translations from English into Norwegian, on the other hand, we are confronted in Figure 3 with a much broader palette of options taken by the translators. 


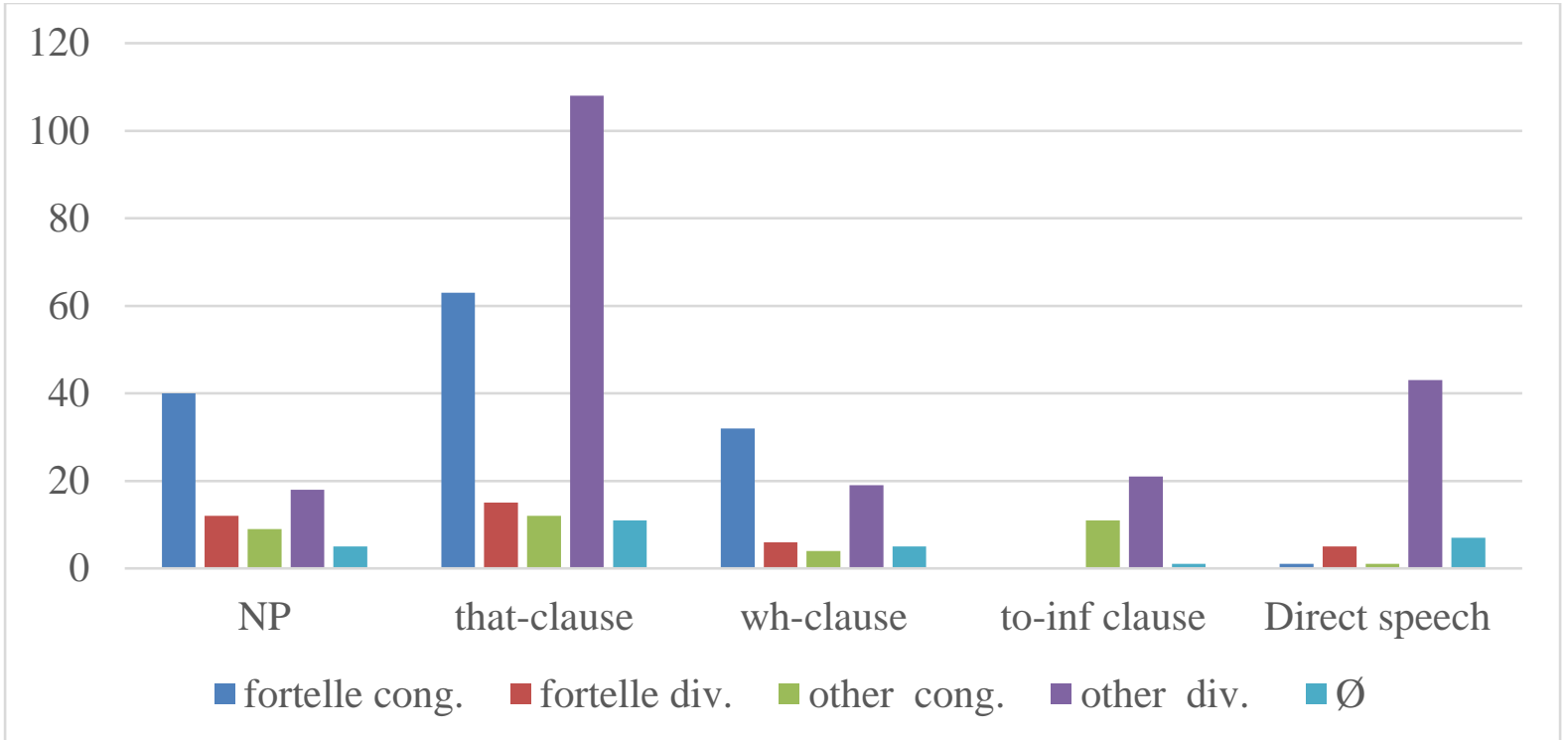

Figure 3. Strategies employed by translators from English into Norwegian in raw numbers.

It is only in the case of NP and wh-clausal THEMEs that translators into Norwegian prefer fortelle as the target verb. Translations of that-clausal THEMEs resemble translations of the two English double object constructions with no Norwegian counterpart in containing more examples with the verb si (say). Table 2 contains details of the most common verbs used in four types of divergent translation into both languages.

Table 2. Lexicogrammatical correspondences in four types of divergent translations.

\begin{tabular}{|c|c|c|c|c|}
\hline & \multicolumn{2}{|c|}{ English translations } & \multicolumn{2}{|c|}{ Norwegian translations } \\
\hline & Total & Verbs & Total & Verbs \\
\hline Omission of RECIPIENT & 8 & $\begin{array}{l}\text { say: } 2 \\
\text { other verb: } 6\end{array}$ & 163 & $\begin{array}{l}\text { fortelle (tell): } 32 \\
\text { si (say): } 109 \\
\text { other verb: } 22\end{array}$ \\
\hline Omission of THEME & 5 & tell: 5 & 0 & \\
\hline $\begin{array}{l}\text { Ditransitive to Prepositional } \\
\text { Dative }\end{array}$ & 1 & other verb: 1 & 59 & $\begin{array}{l}\text { fortelle (tell): } 2 \\
\text { si (say): } 52 \\
\text { other verb: } 5\end{array}$ \\
\hline $\begin{array}{l}\text { Prepositional Dative to } \\
\text { Ditransitive }\end{array}$ & 1 & tell: 1 & 0 & \\
\hline
\end{tabular}

We can see from Figures 3 and 4 and Table 2 that translators in both directions may employ verbs other than the relevant cognate. Tables 3 and 4 contains details of all verbs other than tell and fortelle which are found in both syntactically congruent and syntactically divergent translations. 
Table 3. Verbs other than tell used in translations into English.

\begin{tabular}{|l|l|}
\hline Number & Verbs \\
\hline 4 & say \\
\hline 2 & inform \\
\hline 1 each of & $\begin{array}{l}\text { admit, be reminiscent of, confirm, corroborate, demonstrate, dictate, give, keep secret, } \\
\text { object, outline, perceive }\end{array}$ \\
\hline 13 & Total number of types \\
\hline 17 & Total number of tokens
\end{tabular}

Table 3 shows that there are in all 13 verbs other than tell that are used in English translations of fortelle. Apart from the general communication verb say and the even more general transfer verb give, these are, with two exceptions, either troponyms giving more information than tell about the mode of communication (demonstrate, outline) or more information about the attitude of the speaker to the content of the communication (admit, confirm). The fact that 11 of the 13 verbs in Table 3 are hapaxes indicates that we may here be witness to individual, perhaps even idiosyncratic, choices made by the translators. This impression is reinforced by the fact that two translators are responsible for over half of the verbs other than tell and say (7 of 12).

Table 4. Verbs other than fortelle used in translations into Norwegian.

\begin{tabular}{|c|c|}
\hline Number & Verbs \\
\hline 183 & si (say) \\
\hline 12 & $b e$ (ask) \\
\hline 7 & forklare (explain) \\
\hline 4 & hфre (hear) \\
\hline 2 & forsikre (assure), gi beskjed (give message), gjфre klart (make clear), svare (answer) \\
\hline 1 each of & $\begin{array}{l}\text { bekjentgjøre (announce), bekrefte (confirm), bemerke (comment), beordre (order), } \\
\text { bestemme (decide), erklare (state), formane (urge), få (get), innbille (imagine), } \\
\text { instruere (instruct) love (promise), laere (teach), meddele (inform), mene (think), } \\
\text { minne (remind), nevne (mention), opplyse (inform), overbevise (persuade), presisere } \\
\text { (clarify), proklamere (proclaim), påstå (assert), replisere (reply), servere (serve), } \\
\text { skrive (write), tilstå (confess), tro (believe), true (threaten), utbryte (exclaim), vise } \\
\text { (show) }\end{array}$ \\
\hline 37 & Total number of types \\
\hline 242 & Total number of tokens \\
\hline
\end{tabular}

Over half of the translations of tell predications into Norwegian contain a verb other than fortelle, which may be compared to just $14 \%$ of translations into English containing verbs other than tell (the difference between the two, according to a chi. sq. test, is significant at the $\mathrm{p}=0.05$ level). The general communication verb si (say), which, unlike English say, can take an indirect object (Faarlund et al., 1997: 726), accounts for $76 \%$ of the verbs other than fortelle. The 
second most common verb be (ask) is used to translate English to-infinitive instructions as in (24) and (32).

(32) She hardly spoke to him apart from telling him to go to the shop for five Woodbines. (ST1)

Hun sa nesten aldri et ord til ham, bortsett fra når hun $b a$ ham stikke ned i butikken etter sigaretter til henne. (ST1T)

She said hardly ever a word to him, apart from when she asked him to pop down to the shop for cigarettes for her.

The choice of an ASK verb instead of a TELL verb would appear to alter the illocutionary force of the THEME from an instruction to a request. Since the 12 examples are spread over 11 translators, this change cannot be ascribed to the idiolects of a handful of translators. The most likely explanation for this behaviour is that the ASK verbs in the two languages differ in their force, but it lies outside the scope of this paper to pursue this putative distinction.

There are four examples in which the RECIPIENT is recoded from indirect object of tell to subject of hear. This is an example of the translation technique called 'modulation' by Vinay and Darbelnet (1995: 346), whereby a participant in the source text is encoded in a translation in a different semantic role (as in 'She told it to him' $\rightarrow>$ 'He heard it from her'). The remainder of the verbs in Table 4 resemble the troponyms used in the translations into English in Table 3 by either giving more information than fortelle about the mode of communication (utbryte (exclaim), skrive (write)) or more information about the attitude of the speaker to the content of the communication (formane (urge), tilstå (confess)). The total of 37 different types chosen to translate 449 tokens may be compared to the 47 types employed by translators into English of 382 Dutch tokens of beginnen (begin/start), another common lexeme, in Vandevoorde's study of inchoativity (2020: 82). Vandevoorde actually decided to discard hapaxes from her study of beginnen, regarding these as expressions of translators' idiosyncracies. The 29 hapaxes in my study are dispersed over 16 texts, one translator being responsible for six of them and a further two for three each, indicating that some translators are more idiosyncratic than others.

Table 5 shows the degree of overall mutual lexical and syntactic correspondence (see Altenberg, 1999; Ebeling and Ebeling, 2013: 27) between tell and fortelle in double object constructions, as well as the correspondence in each of the three constructions that occur with both verbs in the ENPC.

Table 5. Mutual correspondence of tell and fortelle.

\begin{tabular}{|c|c|c|c|}
\hline & $\begin{array}{l}\text { Lexical mutual } \\
\text { correspondence }\end{array}$ & $\begin{array}{l}\text { Syntactically congruent } \\
\text { translations }\end{array}$ & $\begin{array}{l}\text { Lexical + syntactic mutual } \\
\text { correspondence }\end{array}$ \\
\hline $\begin{array}{l}\text { In examples with NP } \\
\text { THEMEs }\end{array}$ & $71.1 \%$ & $61.3 \%$ & $54.2 \%$ \\
\hline $\begin{array}{l}\text { In examples with } \\
\text { wh-clausal THEMEs }\end{array}$ & $62.8 \%$ & $59.3 \%$ & $53.5 \%$ \\
\hline $\begin{array}{l}\text { In examples with that- } \\
\text { clausal THEMEs }\end{array}$ & $44.4 \%$ & $43.2 \%$ & $38 \%$ \\
\hline $\begin{array}{l}\text { Overall in double object } \\
\text { constructions }\end{array}$ & $56 \%$ & $51 \%$ & $39 \%$ \\
\hline
\end{tabular}

Table 5 shows that there is a relatively high degree of mutual lexical correspondence between the two verbs in constructions with NP THEMEs. This is also the type of THEME that gives rise 
to the highest incidence of syntactically congruent translations. However, when comparing the percentages in the fourth column to the second and third, we see that the choice of the congruent construction appears more likely to prompt the use of the cognate verb rather than vice versa (the difference between the two is syntactically significant, according to a chi.sq. test at the level of $\mathrm{p}=0.05$ ). With respect to both types of clausal THEMEs, there is a lower degree of both lexical and syntactic correspondence than is the case for NP THEMEs. However, in both cases the two types of correspondence seem to go hand in hand (in both cases the probability of their being a difference between them is $>0.1$ ). That is, if translators of predications containing clausal THEMEs first opt for the cognate verb or the corresponding syntactic construction, they are likely to combine the two in their translation.

\section{French correspondences of Norwegian originals and English translations}

This section is divided into two parts. Section 4.1 contrasts English and French translations of Norwegian original examples of double object fortelle constructions. Section 4.2 takes as it starting point double object tell constructions in the English translations and compares these to the corresponding Norwegian originals and the French translations of these. (There are no English or French source texts in the Norwegian-English-German-French part of the OMC). It should be mentioned at the outset that shorter extracts from three of the texts in the OMC are included in the ENPC, so any contrasts between English and Norwegian that emerge from the data cannot be viewed as independent of those described in section 3 .

\subsection{English and French translations of Norwegian fortelle predications}

There are 94 examples of double object fortelle constructions in the original Norwegian texts in the OMC, 87 of which are ditransitive, the remaining seven being the prepositional dative. Table 6 contains an overview of the English and French verbs used in the two sets of translations.

Table 6. Verbs used in congruent and divergent English and French translations of double-object fortelle predications.

\begin{tabular}{|c|c|c|c|}
\hline \multicolumn{2}{|r|}{ English } & \multicolumn{2}{|r|}{ French } \\
\hline 83 & tell (76 Cong., 7 Div.) & 39 & dire (say: 32 Cong., 7 Div.) \\
\hline 2 & let know (Cong.) & 28 & raconter (tell: 25 Cong., 3 Div.) \\
\hline 1 & $\begin{array}{l}\text { Cong.: give, inform, say } \\
\text { Div.: emphasise, indicate, narrate, point } \\
\text { out, talk }\end{array}$ & 5 & expliquer (explain: 2 Cong., 3 Div.) \\
\hline \multirow[t]{5}{*}{1} & $\varnothing$ & 4 & révéler (reveal: Cong.) \\
\hline & & 3 & parler (speak: 2 Cong., 1 Div.) \\
\hline & & 2 & $\begin{array}{l}\text { faire comprendre (give to understand: } \\
\text { Cong.) }\end{array}$ \\
\hline & & 1 & $\begin{array}{l}\text { Cong.: affirmer (affirm), faire savoir (give } \\
\text { to understand), laisser à penser (give to } \\
\text { think), ne cacher (not conceal), répéter } \\
\text { (repeat) } \\
\text { Div.: addresser (address), indiquer } \\
\text { (indicate), pouvoir savoir (let understand), } \\
\text { prévenir (warn) }\end{array}$ \\
\hline & & 4 & $\varnothing$ \\
\hline 94 & Cong. 81 , Div. $12, \varnothing 1$ & 94 & Cong. 72 , Div. $18, \varnothing 4$ \\
\hline
\end{tabular}


According to the data in Table 6, both sets of translators employ congruent constructions, as in (33), in the majority of cases. The difference between the behaviour of the translators in this respect is marginally significant at the 0.05 level ( $p=0.046$ according to a chi.sq. test). While English translators are more likely to employ a congruent translation of the ditransitive, the opposite is the case with the prepositional dative, with French translators employing congruent translations in five of the seven, and English translators in just two. Four of the divergent English translations contain the ditransitive, as in (34).

(33) Fortell meg straks hvor han er. (NF1)

Tell me at once where he is.

Tell me where he is. (NF1TE) ${ }^{6}$

Dites-moi vite où il est. (NF1TF)

Say me quickly where he is.

(34) Jeg trengte én å fortelle det til at Ana er død. (JG3)

I needed someone to tell it to that Ana is dead.

I needed to tell someone that Ana is dead. (JG3TE)

J'avais besoin de dire à quelqu'un qu'Ana était morte. (JG3TF)

I had the need to say to someone that Ana was dead.

Among the French translations of the prepositional dative there is one, (35), which contains a double coding of the RECIPIENT. This sort of double coding does not occur in either English or Norwegian, but can be used in French when the speaker wishes to emphasise the RECIPIENT.

(35) Det fortalte han til deg? (JG3)

That told he to you?

He said that to you? (JG3TE)

Il t'a raconté ça, à toi? (JG3TF)

He you told that, to you?

The results in Table 6 are in line with those in section 3.3, which showed that tell is by far the most likely English translation of fortelle. In fact, (35) is the only case where the English translator employs the verb say. In French, on the other hand, the verb dire is more commonly used than the verb raconter. The difference between the two languages with respect to these verbs of SAYING and TELLING is illustrated in Table 7.

Table 7. Basic English and French verbs of TELLING and SAYING.

\begin{tabular}{|l|l|l|}
\hline Verbs of TELLING / SAYING & English target texts & French target texts \\
\hline + RECIPIENT & tell & raconter \\
\hline & & dire \\
\hline - RECIPIENT & say & \\
\hline
\end{tabular}

The categorisation in Table 7, although it employs the notation of semantic componential analysis, is merely intended to illustrate the prototypical senses of the communication verbs. The verb that displays the least constructional variation in the translated data is raconter, which only occurs in three divergent translations, according to Table 6. In all three of these the prepositional dative replaces the ditransitive, as in (36).

\footnotetext{
6 'TE' and 'TF' stand for translated text in English and French respectively.
} 
(36) Lorch fortalte Dina mange rare ting. (HW2)

Lorch told Dina many strange things. (HW2T)

Lorch racontait à Dina des tas de choses bizarres. (HW2TF)

Lorch told to Dina lots of strange things.

Table 8 contains details of how often the two French verbs dire and raconter are used to translate the three syntactic types of THEME in the Norwegian originals.

Table 8. Types of THEME in Norwegian original texts translated by dire and raconter.

\begin{tabular}{|l|c|c|c|c|}
\hline & NP & that-clause & wh-clause & Total \\
\hline dire & 8 & 12 & 19 & 39 \\
\hline raconter & 20 & 3 & 5 & 28 \\
\hline
\end{tabular}

We see in Table 8 that raconter is more than twice as likely as dire to occur with an NP THEME. Moreover, eight of these 20 NPs contain the word historie (story), either standing alone, as in (37), or as part of a compound, such as godnatthistorie (bedtime story) or løgnhistorie (fake story).

(37) Så hadde han bestemt seg og ga seg til å fortelle meg en historie. (BBH1)

Then he had made up his mind and set about telling me a story.

Then his decision was made, and he told me a story. (BBH1TE)

Puis, ayant pris sa décision, il s'est mis à me raconter une histoire. (BBH1TF)

Then, having made his decision, he started me telling a story.

The fact that the various events in a story are told consecutively serves to explain the common origin of the present-day French verbs (ra)conter and compter (to count), as it does the relationship between the Norwegian verbs fortelle and telle (to count). ${ }^{7}$ As for English, according to the OED the verb tell was used in the sense 'to count', side by side with the recount sense, from Old English up until the eighteenth century. ${ }^{8}$

\subsection{English translations, Norwegian originals and their French translations}

According to Table 6 there are 83 examples of Norwegian double object fortelle predications translated into English by tell. Three translations substitute the ditransitive for the prepositional dative, the remaining four contain just one object. This leaves 79 double object tell examples translating double object fortelle. In actual fact, however, these 79 examples represent fewer than a third of the 272 examples of double object tell constructions in the translations in the OMC. In this section, we will examine what sort of constructions trigger the other 193 uses of $t e l l$, and how the French translators respond to these same verbal triggers. Five of the examples translate monotransitive fortelle, leaving 188 examples containing other verbs. The verb si (say) occurs in $102(37.5 \%)$ of the Norwegian originals. Table 9 contains details of three si constructions, monotransitive (MT), ditransitive (DT) and prepositional dative (PD), and their French translations.

\footnotetext{
7 The nouns conte (French), fortelling (Norwegian) and tale (English) are all related to the TELL verbs and all denote informal stories, often oral in origin.

${ }^{8}$ The expression 'to tell the time' displays a fossilised use of the 'count' sense. It originally referred to the practice of ascertaining the time by counting the ringing of the church bells.
} 
Table 9. French translations of Norwegian si (say) predications translated into English by double object tell.

\begin{tabular}{|c|c|c|c|}
\hline \multicolumn{2}{|c|}{ Norwegian originals } & \multicolumn{2}{|r|}{ French translations } \\
\hline \multirow[t]{4}{*}{51} & \multirow[t]{4}{*}{ MT si } & 19 & DT dire (say) \\
\hline & & 12 & MT dire (say) \\
\hline & & 1 each of & $\begin{array}{l}\text { MT: ajouter (add), éclairer (throw light on), expliquer } \\
\text { (explain), faire valoir (maintain), raconter (tell), répeter } \\
\text { (repeat), répondre (answer) } \\
\text { DT: annonser (announce), avouer (swear), demander (ask), } \\
\text { donner (give), expliquer (explain), ordonner (order), prévenir } \\
\text { (warn) } \\
\text { PD: ordonner (order) } \\
\text { IT*: demander (ask) }\end{array}$ \\
\hline & & 4 & 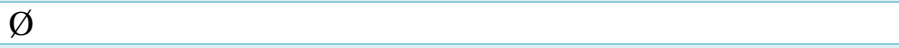 \\
\hline \multirow[t]{3}{*}{27} & \multirow[t]{3}{*}{ DT $s i$} & 19 & DT dire (say) \\
\hline & & 1 each of & $\begin{array}{l}\text { MT: répondre (answer), constater (remark) } \\
\text { DT: montrer (show), écriver (write) } \\
\text { PD: asséner (strike) }\end{array}$ \\
\hline & & 3 & $\varnothing$ \\
\hline \multirow[t]{7}{*}{24} & \multirow[t]{7}{*}{$\mathrm{PD} s i$} & 9 & DT dire (say) \\
\hline & & 3 & PD dire (say) \\
\hline & & 1 & DT + PD dire (say) \\
\hline & & 1 & MT dire (say) \\
\hline & & 2 & DT répéter (repeat) \\
\hline & & 1 each of & $\begin{array}{l}\text { MT: donner l'ordre (order), penser (think), souffler (murmur) } \\
\text { DT: avouer (swear), convaincre (convince), rassurer (reassure) }\end{array}$ \\
\hline & & 2 & $\varnothing$ \\
\hline
\end{tabular}

$63 \%$ of the translations of si in Table 9 contain the verb dire, with the ditransitive dire construction being the most frequent translation, irrespective of whether the Norwegian originals are monotransitive, as in (38), ditransitive, as in (39), or prepositional dative, as in (40).

(38) - Hva var det jeg sa? utbrøt hun. (JG3)

- What was it I said? she burst out.

"What did I tell you?" she cried. (JG3TE)

— Qu'est-ce que je t'avais dit! s'exclama-t-elle. (JG3T)

What is it I you said! exclaimed she.

(39) Men øynene hennes sa ham hvem han tilhørte. (HW2)

But her eyes said him who he belonged to.

But her eyes told him to whom he belonged. (HW2TE)

Mais ses yeux lui disaient à qui il appartenait. (HW2TF)

But her eyes him said to whom he belonged.

(40) Jeg sa til meg selv at jeg måtte glemme denne dagen. (NF1)

I said to myself that I must forget this day.

I told myself I would have to forget that day. (NF1TE)

Je me dis que je devais oublier cette journée. (NF1TF)

I me say that I should forget this day.

In both (38) and (40), the salient correspondence of si in French, dire, is utilised, but not the most similar syntactic construction. Most striking perhaps is the extent to which the translators 
resort to a ditransitive construction to translate monotransitive $s i .{ }^{9}$ There would appear to be a felt need to mention the RECIPIENT explicitly on the part of translators into English and French, both sets of whom appear to be influenced by the "gravitational pull" of the target language grammar (Halverson 2007), rechristened "magnetism" by Halverson (2017).

Before looking at other Norwegian forms that are translated into English by double object tell, I should point out that the si originals in Table 9 represent just 5\% of the total number of occurrences containing the verb si in the original Norwegian texts. The majority of these are monotransitive and are translated into English by monotransitive say, and into French by monotransitive dire. In all over 20 French verbs are used to translate the Norwegian si predications in Table 9, all of which correspond to English double object tell translations. All of these verbs are more explicit with respect to the mode or force of communication than Norwegian si. According to Nádvorníková (2020) the proportion of neutral reporting verbs (like say and tell) in original texts in her corpus was $60 \%$ for English and 50\% for French, indicating a preference for a wider variety of reporting verbs in French, a preference she found reflected in a greater degree of explicitation in translations from English to French than vice versa (Nádvorníková, 2020: 223).

In addition to fortelle and $s i$, there are in all 36 Norwegian verb types that give rise to double object tell translations. These account for 79 tokens. There are six zero translations and one where the English verbal predication translates a Norwegian nominal. Considerations of space dictate that just the two most common of these Norwegian verbs will be exemplified here. These are forklare (explain) with 14 tokens, and be (ask) with ten tokens. Of the 14 examples of forklare, 13 are translated into French by expliquer, as in (41). Expliquer is also occasionally used to translate fortelle (Table 6) and si (Table 9).

(41) Jeg forklarte Idun at hun måtte skynde seg. (BHH1)

I explained Idun that she had to hurry herself.

I told Idun to hurry up. (BHH1TE)

J'ai expliqué à Idun qu'elle devrait faire vite. (BHH1TF)

I explained to Idun that she had to make haste.

While forklare is almost always translated by French expliquer (this is also the case in the 75 examples where it does not prompt a tell construction in English), there is no single French verb that stands out in translations of Norwegian be (ask). Of the ten examples, three are translated by prier (beg), as in (42), and two by demander (ask), as in (43).

(42) Jeg ber ham ta det rolig. (NF1)

I ask him to take it easy.

I told him to compose himself. (NF1TE)

Je le prie de rester tranquille. (NF1TF)

I him beg to stay relaxed.

(43) Til sist bad jeg henne om å holde opp. (JG3)

Finally asked I her to cut it out.

Finally I told her to stop. (JG3TE)

Je lui ai demandé d'arrêter. (JG3TF)

I her (have) asked to stop.

The French translations of (42) and (43) incorporating prier and demander appear to mirror the semantics of the source texts. The English translations appear to alter, and not merely explicitate, the semantics of the reporting verb, as discussed in relation to the opposite direction

\footnotetext{
${ }^{9}$ This preponderance of the ditransitive is in line with the findings of Malvar Mouco and Pino Serrano (2006: $560) .16 .5 \%$ of dire tokens in their material are ditransitive, compared to $1.7 \%$ prepositional dative.
} 
of translation (of tell by be) in section 3.3. (See Winters, 2007: 420 for a discussion of some translations between German and English that alter the semantics of verbal predications.)

There are six cases where English tell does not translate directly a predication in the Norwegian original. In some of these, as in (44), the French translation is faithful to the original, in others, such as (45), there is no expression in either English or French corresponding to the Norwegian expression.

(44) Eller at hun satte dem $i$ gang med å telle alle ting som var i rommet. (HW2) Or that she got them going with counting all the things that were in the room.

Or she told them to start counting everything in the room. (HW2TE)

Ou encore elle les mettait à compter tous les objets qui se trouvaient dans la pièce. (HW2TF)

Or else she them put to count all the objects that were located in the room.

(45) Erfaringsmessig er det naturligvis umulig at Ana var den gamle malerens modell. (JG3)

Experience-wise is it naturally impossible that Ana was the old painter's model. Experience tells us it is inconceivable that Ana was the Old Master's model. (JG3TE) Naturellement, nous savons par expérience qu'il est impossible qu'Ana ait été le modèle du peintre. (JG3TF)

Naturally, we know from experience that it is impossible that Ana has been the model of the painter.

The translators of (45) have chosen different options, both of which were available to both of them: that is the English translator could have written "we know from experience that" and the French one "l'expérience nous dit que".

To summarise this section on the Norwegian originals underlying English tell translations and their corresponding French translations, two points stand out. The first is the large number of verbs in both the Norwegian and French versions that correspond to English double object tell predications. The second is the number of SAY verbs ( $s i$ and dire) that correspond to tell. In fact, if one were to subject si and dire to an Anglo-centric classification, it might be more accurate to label them TELL verbs, as they both occur in the ditransitive construction as well as the prepositional dative. Of the two, dire is the more common in my data. Thus, to the somewhat impressionistic picture of the relationship between English and French verbs of SAYING and TELLING in Table 7, we can now add information about their Norwegian correspondences, as in Table 10.

Table 10. Basic English, Norwegian and French verbs of TELLING and SAYING.

\begin{tabular}{|l|l|l|l|}
\hline Verbs of telling/saying & English & Norwegian & French \\
\hline + RECIPIENT & tell & fortelle & raconter \\
\hline - RECIPIENT & & si & dire \\
\hline
\end{tabular}




\section{Summary and conclusion}

This paper has presented the results of two related studies of ditransitive communication constructions. The first study, presented in section 3, is based on data from the ENPC and contrasts the occurrences of double object constructions containing the cognate verbs English tell and Norwegian fortelle, both in original texts in the two languages and in translations of these. The second study, presented in section 4, is based on data from the OMC and contrasts English and French translations of Norwegian double object fortelle predications. It also looks at all the double object tell constructions in the English translations and compares these to the corresponding Norwegian originals and the French translations of these.

Three research questions were presented in section 1. The first question asked about the degree of similarity between the verbs tell and fortelle with two objects in the original texts in English and Norwegian. It turns out that there are considerable differences in the lexicogrammatical behaviour of the two verbs in double object constructions. They differ much more in their lexicogrammar than the two GIVE lexemes give and gi. Tell is more than four times as common and occurs with a greater syntactic variety of THEMEs than fortelle, while the latter occurs much more often than tell in the prepositional dative construction.

The second question asks whether there are some kinds of tokens that are usually translated by congruent constructions. It was answered in section 3.3 by comparing the target texts in Norwegian and English with their sources. It transpires that tokens with NP THEMEs are those most often translated congruently, 65\% in the direction Norwegian->English and $60 \%$ in the direction English->Norwegian. This is also the type of THEME that sees the most translations containing the cognate lexeme. Moreover, a decision on the part of translators to employ the congruent construction increases the likelihood of their employing the cognate verb. Perhaps the most striking feature of the Norwegian translations is the tendency to employ the verb si (say). This tendency is no doubt facilitated by the fact that si, unlike its English cognate say, can take an indirect object, enabling translators to retain the syntactic construction in their translations, while opting for a more common neutral reporting verb. Translators into Norwegian also employ a greater variety of verbs to translate tell than do English translators of fortelle predications.

The third question asked about the French translation correspondences of the English and Norwegian constructions. It was answered in section 4 by comparing the French and English translations to one another and to their Norwegian sources. The results show that French resembles Norwegian in several respects. In the first place since the verb dire, like Norwegian si, can take an indirect object, this renders it an appropriate correspondent of many English ditransitive tell predications. In the second place French contains a more specialised TELL verb, raconter, which resembles Norwegian fortelle in being more restricted in its distribution than English tell. And thirdly, there is a large number of other verbs that are used to translate the Norwegian originals that give rise to double object tell. There is, however, one respect in which the French translations resemble their English counterparts, namely the addition of an explicit RECIPIENT in translations of original Norwegian monotransitive sentences.

To round off, it is appropriate to ask what, if anything, this study has contributed to our knowledge of double object communication constructions. The fact that English tell corresponds in large measure to Norwegian si and French dire comes as no surprise. Indeed, dire precedes raconter in the French definition of tell in the bilingual Concise Oxford-Hachette French Dictionary (1998). More surprising, given the evidence of Table 6 that dire is the single most common verb used to translate double object fortelle, is the omission of dire from the definition of fortelle in the bilingual Norwegian-French dictionary Fransk Blå Ordbok (2002), which gives raconter and faire le récit de as its primary correspondents. Another point worth noting is the number of Norwegian and French communication verbs that correspond to English 
$t e l l$, in addition to the large number of correspondences with si and dire, which serves to further underline the polysemous nature of the English verb.

In order to get a fuller picture of the distribution of the cognate verbs tell and fortelle, and of French raconter, future studies should take into account their occurrence in monotransitive and passive constructions. It would also be an advantage to expand the data to include SAY verbs in all three languages as well as original texts in all three, since the subcorpus of the OMC used in the present study is mono-source. A final point concerns the broader topic of cognate verbs in English and Norwegian that partake of the dative alternation. It was shown in Egan (forthcoming) that the distribution of the physical transfer GIVE verbs was very similar in the two languages. We have now seen that the distribution of the message transfer TELL verbs is quite different. Further studies will flesh out the picture by investigating verbs such as those of temporary transfer, LEND verbs, those of ownership transfer, SELL verbs, and those of accompanied transfer, BRING verbs.

\section{References}

Åfarli, T.A. 1992. The Syntax of Norwegian Passive Constructions. Amsterdam: John Benjamins.

Altenberg, B. 1999. Adverbial Connectors in English and Swedish: Semantic and Lexical Correspondences. In Out of Corpora: Studies in Honour of Stig Johansson, H. Hasselgård and S. Oksefjell (eds), 249-268. Amsterdam: Rodopi.

Andersen, M., Fikkert, P., Mykhaylyk, R. and Rodina, Y. 2012. The Dative Alternation in Norwegian Child Language. Nordlyd 39:1: 24-43.

Biber, D., Johansson, S., Leech, G., Conrad, S. and Finegan, E. 1999. Longman Grammar of Spoken and Written English. Harlow: Longman.

Bourne, J. 2002. He said, she said: Controlling Illocutionary Force in the Translation of Literary Dialogue. Targets 14:2: 241-261.

Bresnan, J. and Hay, J. 2008. Gradient Grammar: An Effect of Animacy on the Syntax of Give in New Zealand and American English. Lingua 118: 245-259.

Bresnan, J. and Ford, M. 2010. Predicting Syntax: Processing Dative Constructions in American and Australian Varieties of English. Language 86:1: 168-213.

Brøseth, H. 1998. Dobbelt objekt og tilgrensende konstruksjoner i moderne norsk. In MONS 7: Utvalde artiklar frå det 7. møtet om norsk språk $i$ Trondheim 1007, J.T. Faarlund, B. Mæhlum and T. Nordgård (eds), 13-34. Oslo: Novus.

Ebeling, J. 1998. Using Translations to Explore Construction Meaning in English and Norwegian. In Corpora and Cross-linguistic Research: Theory, Method and Case Studies, S. Johansson and S. Oksefjell (eds), 169-195. Amsterdam: Rodopi.

Ebeling, J. and Ebeling, S.O. 2013. Patterns in Contrast. Amsterdam: John Benjamins.

Egan, T. forthcoming. Giving in English and Norwegian: A Contrastive Perspective. In Ditransitive Constructions in Germanic Languages, M. Röthlisberger, E. Zehentner and T. Colleman (eds), Amsterdam: John Benjamins.

Faarlund, J.T., Lie, S. and Vannebo, K.I. 1997. Norsk Referansegrammatikk. Oslo: Universitetsforlaget.

Halverson, S.L. 2007. Investigating Gravitational Pull in Translation: The case of the English Progressive Construction. In Text, Processes, and Corpora: Research Inspired by Sonja Tirkkonen-Condit, R. Jääskeläinen, T. Puurtinen and H. Stotesbury (eds), 175-196. Joensuu: University of Eastern Finland.

Halverson, S. L. 2017. Gravitational Pull in Translation. Testing a Revised Model. In Empirical Translation Studies. New Methodological and Theoretical Tradition, G. De Sutter, M-A. Lefer and I. Delaere (eds), 9-46. Berlin: Mouton de Gruyter.

Huddleston, R.D. and Pullum, G.K. 2002. The Cambridge Grammar of the English Language. Cambridge: Cambridge University Press.

Johansson, S. 2007. Seeing through Multilingual Corpora: On the Use of Corpora in Contrastive Studies. Amsterdam: John Benjamins. 
Levin, B. 1993: English Verb Classes and Alternations: A Preliminary Investigation. Chicago: University of Chicago Press.

Lohndal, T. 2011. Freezing Effects and Objects. Journal of Linguistics. 47:1: 163-199, 249-250.

Malvar Mouco, S. and Pino Serrano, L. 2006. Dire et répondre, un couple à comparer. In Studies in Contrastive Linguistics: Proceedings of the 4th International Contrastive Linguistics Conference: Santiago De Compostela, September, 2005, C. Mourón Figueroa and T. Iciar Moralejo Gárate (eds), 557-566. Santiago de Compostela: Universidade de Santiago de Compostela.

Mayle, P. 1989. A Year in Provence. London: Hamish Hamilton.

Mukherjee, J. 2005. English Ditransitive Verbs: Aspects of Theory, Description and a Usage-based Model. Amsterdam: Rodopi.

Nádvorníková, O. 2020. Differences in the Lexical Variation of Reporting Verbs in French, English and Czech Fiction and their Impact on Translation. Languages in Contrast, 20: 2: 209-234.

Paradis, M. 2004. A Neurolinguistic Theory of Bilingualism. Amsterdam: John Benjamins.

Pípalová, R. 2012. Framing Direct Speech: Reporting Clauses in a Contrastive Study. Prague Journal of English Studies 1:1: 75-107.

Quirk, R., Greenbaum, S., Leech, G. and Svartvik, J. 1985. A Comprehensive Grammar of the English Language. London: Longman.

Röthlisberger, M., Grafmiller, J. and Szmrecsanyi, B. 2017. Cognitive Indigenization Effects in the English Dative Alternation. Cognitive Linguistics 28:4: 673-710.

Szmrecsanyi, B., Grafmiller, J, Bresnan, J., Rosenbach, A., Tagliamonte, S. and Todd, S. 2017. Spoken Syntax in a Comparative Perspective: The Dative and Genitive Alternation in Varieties of English. Glossa 2:1: 1-27.

Tungseth, M.E. 2008. Verbal Prepositions and Argument Structure: Path, Place and Possession in Norwegian. Amsterdam: John Benjamins.

Vandevoorde, L. 2020. Semantic Differences in Translation: Exploring the Field of Inchoativity. Berlin: Language Science Press.

Viberg, Å. 1996. Cross-linguistic Lexicology. The Case of English go and Swedish gå. In Languages in Contrast: Papers from a Symposium on Text-based Cross-linguistic Studies, Lund 4-5 March 1994, K. Aijmer, B. Altenberg and M. Johansson (eds), 151-182. Lund: Lund University Press.

Vinay, J-P. and Darbelnet, J. 1995. Comparative Stylistics of French and English: A Methodology for Translation. Translated and edited by J.C. Sager and M-J. Hamel. Amsterdam: John Benjamins.

Winters, M. 2007. F. Scott Fitzgerald's Die Schönen und Verdammten: A Corpus-based Study of Speech-act Report Verbs as a Feature of Translators' Style. Meta: Journal des traducteurs 52: 412-425.

\section{Corpora and dictionaries}

English-Norwegian Parallel Corpus https://www.hf.uio.no/ilos/english/services/knowledge-resources/omc/enpc/ [Last accessed 1 June 2021].

Oslo Multilingual Corpus http://www.hf.uio.no/ilos/english/services/omc/ [Last accessed 1 June 2021].

Dictionnaire de l'Académie, neuvième édition. http://atilf.atilf.fr/academie9.htm [Last accessed 1 June 2021].

Corréard, M.-H. and Grundy, V. 1998. The Concise Oxford-Hachette French Dictionary. Oxford: Oxford University Press.

Elligers, A. and Jacobsen, T. 2002. Fransk Blå Ordbok. Oslo: Kunnskapsforlaget. 
Thomas Egan

Author's address

Thomas Egan

Department of Humanities

Inland Norway University of Applied Sciences

Holsetgata 31

NO-2318 Hamar

Norway

thomas.egan@inn.no 